\title{
The Use of Loanwords in Emirati Arabic According to Speakers' Gender, Educational Level, and Age
}

Abdul Salam Mohamad Alnamer, Sulafah Abdul Salam Alnamer*

College of Education, Humanities and Social Sciences, Al Ain, University of Science and Technology, P.O. Box: 64141 Al Ain, UAE

Corresponding Author: Sulafah Abdul Salam Alnamer, E-mail: sulafah.asa@gmail.com

\section{ARTICLE INFO}

Article history

Received: February 04, 2018

Accepted: April 12, 2018

Published: July 01, 2018

Volume: 7 Issue: 4

Advance access: May 2018

Conflicts of interest: None

Funding: None

\begin{abstract}
This study aims at identifying the loanwords commonly used in Emirati Arabic (EA), determining their origins and identifying the reasons behind using them. It also investigates the impact of gender, education, and age of speakers of EA on the use of loanwords. To meet these ends, a questionnaire was designed and distributed among 90 speakers of EA who were then classified into three groups: 1) gender; females and males, 2) education; educated and uneducated, and 3) age; young and old. The results show that female EA speakers, educated EA speakers, and young EA speakers use loanwords more than their counterparts in their specific groups. Moreover, the results show that EA speakers use loanwords of different origins like English, Persian, Hindi, and Turkish in addition to a few words of French, Italian, German, and Spanish. The study discusses the possible reasons for these results and concludes with some recommendations for further research.
\end{abstract}

Key words: Loanwords, Emirati Arabic, Gender, Educational Level, Age

\section{INTRODUCTION}

One of the most observable and interesting results of the intercultural contact among languages is the borrowing of words. In fact, no language in the world is completely free of 'loanwords', and this is why this phenomenon has been an attractive field for investigation for researchers (Uffmann, 2006; Haspelmath \& Tadmor, 2009; Alahmadi, 2015 among others). Language can never perish; vocabulary is always enriched by the production of new words by different means, i.e., by morphological means or by the development of polysemy (Alnamer, 2017). Morphologically, some words are no longer used while new words are added to the language in different ways, among which is borrowing words from other languages (AlSaidat, 2011). Borrowing words could be either for showing prestige or for filling a gap in a language (Hockett, 1958). It can also come by conquest or political and cultural domination (Robins, 1964). The use of loanwords can be influenced by many social factors, such as gender, education, and age.

In the present study, the focus is placed on Emirati Arabic (henceforth EA), one of the Gulf Arabic dialects spoken in the United Arab Emirates (UAE). This study investigates the use of different loanwords in EA. Specifically; it aims at identifying the loanwords commonly used by EA speakers, the origins of these words, and the reasons behind using them. Since social variables such as gender, education, and age are at play in a language community's selection of words, this study also examines whether these variables influence the use of loanwords by EA speakers and how.

\section{LITERATURE REVIEW}

\section{Loanwords}

'Loanwords' are words borrowed from one language into another (Kang, 2011). The language from which a word is borrowed is called 'the donor language', and the language into which it is borrowed is called 'the recipient language' (Haspelmath, 2009).

According to Hockett (1958), people borrow words for two reasons: showing prestige and filling a gap in their language. They tend to show prestige and imitate those whom they admire or wish to be identified with and to be treated as they are. For example, bobby soxers ${ }^{1}$ are well known for imitating the most popular singers and TV or radio stars (Hockett, 1958). Moreover, people tend to borrow words to fill a gap in their idiolect ${ }^{2}$. This occurs as a result of new experiences, objects, and practices that people are confronted with, either by 'diffusion' or by 'migration', and for which they do not have equivalents in their idiolect (reference with page number). In his 'A Course in Modern Linguistics', Hockett (1958, p.405) illustrates this point as follows:

We can imagine a British sailing-vessel in China waters in the earliest days of the China trade, manned by a mixed crew. A Chinese crewman notices a cloud-formation on the horizon and in terror cries out his word for the kind of storm that impends. After the storm, the English-speaking members of the crew are all too willing to admit that it is unlike anything in their previous experience and needs its own name; they adopt the Chinese word 'typhoon'. 
Robins (1964) states that loanwords come about as a result of conquest, or political and cultural domination. This is supported by Myers-Scotton (2002), who shows how French had a significant impact on English, as the French culture was in a higher status and was more prestigious and refined compared to English during the Norman Conquest. From 1066 and for a few centuries, French became the language of government and of the upper classes in English society. French also provided English with vocabulary in the areas of law and government, social ranking, court titles, military, and even of food (Hoffer, 2005).

Two linguistic phenomena are usually confused, namely, loanwords and code switching. Although many studies have been conducted to draw a clear line between these two phenomena, the difference between them remains, to some extent, vague (Kistler, 2005). However, some researchers contrast between them on a basic level. According to AlSaidat (2011), code-switching is when bilinguals alternate between different languages momentarily and infrequently while loanwords are recurrent, permanently present and used by monolinguals who are not aware of the foreign origin of these words.

\section{Gender-based Influence on the use of Loanwords}

'Gender' refers to the psychological, social, and cultural differences between males and females (Giddens 1989). According to Chambers (2009), there is a long record of evidence of female verbal superiority. However, this female advantage is slight and mostly attributed to females' use of prestigious language features. Females, in their speech, usually seek prestige and modernity. They are encouraged to use more standard, prestigious, and linguistically polite language (Hugar, 1982; Altakhaineh and Rahrouh, 2015), because society expects them to behave more properly than males, since they serve as speech models for their children (Hugar, 1982).

The use of prestigious language involves the use of loanwords, and concerning this, females have more positive attitudes than males towards loanwords (Vegt, 2014). Van Der Sijs (2005) and Gramley (2001) state that Dutch females have more positive attitudes towards English loanwords than male participants as English conveys 'prestige' in the Netherlands.

This goes side by side with the results of Al Btoush's (2014) study in which he explores English loanwords in colloquial Jordanian Arabic and the reasons behind their increase in the daily speech of a sample of students at Mu'tah University in Jordan in terms of gender and faculty ${ }^{3}$. With regard to gender, the females' positive responses outnumbered those by the males', as the former consider using English words prestigious, since it is the international language, and high-class people know more than their mother tongue.

But this is not always the case; Alahmadi (2015) investigates the degree of lexical variation in Urban Meccan Hijazi Arabic (UMH) by identifying the loanwords that are commonly used, determining their origins, and exploring the effect of age, sex and educational level on the use of loanwords by UMH speakers. Specifically, she states that men use more loanwords than women. Many men in Mecca speak Turkish or Persian fluently. This is due to the fact that they have more opportunities to work outside and contact with pilgrims who speak different languages. On the other hand, women's use of the loanwords could be less because they are more eager to speak like young women in Jeddah as they claim the dialect spoken there is more prestigious. In other words, women in Mecca are more likely to be affected by their regional dialect norms, as they do not leave Mecca to work in other places.

\section{Education-based Influence on the use of Loanwords}

As noted by Koka (2014), the speech of the literate and illiterate people exhibits remarkable variations in terms of the lexical items they use and the pronunciation of many words. In his study on phonological and lexical variation among the Kashmiri speakers, taking into account certain social variables such as religion, education, region/socioeconomic status, age and occupation, he found that literate people tend to use Standard-Kashmiri. This is because they have more opportunities to deal with speakers of standard Kashmiri as office goers. On the other hand, illiterate people use the non-standard Kashmiri because they do not have much contact with speakers of standard Kashmiri. Moreover, Koka (2014) states that the literate group tends to remain up to date with the latest advances in modern inventions. Hence, they borrow many lexical items from other languages like English.

According to Alahmadi (2015), the educational level of the participants plays a role in their use of loanwords in Urban Meccan Hijazi Arabic (UMH). As far as education is concerned, the results of her study demonstrate that the uneducated participants use loanwords more than the educated ones. Alahmadi (2015) argues that the uneducated participants use loanwords in their speech because they want to identify themselves as true Meccans. This is because such a behavior indicates that they will be honored with serving pilgrims, who come to visit Mecca every year. The educated participants, in contrast, have university degrees. Thus, they show that to others using alternative words in Modern Standard Arabic (MSA). This is due to the fact that being able to use MSA correctly is regarded as prestigious since it is the only official variety of Arabic, and it is the language of the holy Quran. Furthermore, they may consider the use of loanwords in UMH as non-prestigious as they believe that the use of loanwords is associated with the local language and the variety spoken in the streets. Nonetheless, many of the educated participants answered the questionnaire by providing some English words instead of words in UMH. This was ascribed to the fact that they wanted to show that they can speak English, which is also considered prestigious.

In some cases, using loanwords can be a mark of the educated person. As discussed by Hoffer (2002), early in Japan, speaking Chinese was an indication of the educated class. In addition, using English has functioned as a marker of education and prestige, and high levels of competence in written and spoken English has been required for being accepted at many top universities. This, therefore, encourages 
the borrowing of words and leads to their use as a mark of being educated.

\section{Age-based Influence on the use of Loanwords}

There have been a number of studies that present 'age' as an important social factor that influences the use of loanwords. The speech of older speakers and their attitudes towards using loanwords are different from those of younger ones.

In an English loanword processing study on Norwegian speakers conducted to discover whether they process English loanwords differently depending on how Norwegianized the word form is, and With regard to their age in particular, Kuitert (2013) states that young people in Norway are the most receptive to new lexical input. They are daily introduced to new English words through technology, music, films, games, TV-shows and social mediums, such as YouTube, Facebook, and Twitter. They prefer to use English loanwords as these words elevate their social status in their speech community. Further, Kuitert (2013) states that older speakers use more Norwegian words than English loanwords, since they have not had the same amount of contact with the English language. Moreover, they refrain from using loanwords of many new fields, like technology, because these are fields they would not undertake. Generally speaking, attitudes to language tend to change with age (Baker, 1995). According to Eckert (1998), as people become older, their speech gets more conservative. Conversely, Vegt (2014) disagrees with Eckert (1998) in his study on the attitudes towards English loanwords in Dutch news broadcasts. He states that adolescents' language attitudes tend to be negative towards traditional language use, and positive towards innovations like loanwords, whereas adults' language attitudes towards such innovations are negative.

Young generations seek modernity and prestige even in their linguistic style. Speaking about modernity, it is important to note that English is attached to modernity and globalisation (Zenner, Speelman \& Geeraerts, 2013), and is one of the most requisite and influential languages in the world (Vegt, 2014). This is exemplified by Alahmadi (2015), who found that younger speakers of UMH prefer to use English loanwords as English is considered prestigious and modern, while older speakers of UMH tend to use more of the Turkish or Persian loanwords. Old Meccan people have been impressed and influenced by the Turkish civilization and language. At the time of the Ottoman occupation of Saudi Arabia, when old Meccan people were younger, they showed their prestigious behavior using the same words used by high class Turks. They also learnt Persian as a result of the contact with Iranians pilgrims and traders. Old Meccan people served and communicated with Turkish and Iranian pilgrims who were considered the richest and the most prestigious compared to others, the thing which encouraged them to pick up many lexical items from these languages. It can be observed that both young Meccan speakers and old Meccan speakers have been influenced by the languages of the dominant and most prestigious cultures they had contact with; previously, they were Turkish and Persian. Today, it is English.

\section{The Research Gap and the Research Questions}

The phenomenon of 'loanwords' is one of the inevitable results of the interaction among nations and an attractive field for researchers to embark on their studies. Various sociolinguistic studies have been conducted to investigate this phenomenon and the influence many social factors like gender, education, and age have on using it (e.g. Alahmadi, 2015; Al Btoush, 2014; and Vegt, 2014).

With regard to Emirati Arabic, which is the focus of this study, Altakhaineh and Rahrouh (2017) investigate the attitudes of Emirati speakers towards their dialect and the extent to which age and gender have an impact on the speakers' perspectives of the their dialect. In another study, Owens, Dodsworth, and kohn (2013) statistically track subjects in Emirati Arabic in terms of two major categories of subject expression: 'null subjects' vs. 'overt subjects' and 'subject-verb'vs. 'verb-subject'. Finally, Mazid (2006) examines some aspects of politeness in Emirati Arabic and translates a number of its politeness formulas into English. However, to the best of our knowledge, little attention has been given to analysing loanwords used by Emirati speakers, which leaves us with a research gap that this study seeks to bridge.

The research gap has led to the formulation of the following questions:

Q1: What are the loanwords commonly used by speakers of Emirati Arabic? And what are their origins?

Q2: What are the reasons behind using these words?

Q3: Do the 'gender', the 'educational level', and the 'age' of the speakers of Emirati Arabic have an impact on their use of these words? If so, how?

This study aims at providing potential answers to these questions to obtain a better understanding of Emirati Arabic. The next section describes the methodology adopted in the current study.

\section{METHODOLOGY}

\section{Participants}

The participants of this study were 90 Emiratis. We randomly distributed the questionnaire to speakers of EA in different places like schools, universities, and clinics. We also used snowball sampling to find more participants, as some participants, as Berg (1988) puts it, were asked to recruit their acquaintances into the sample, especially those who were difficult to locate, such as the old speakers of EA. Since the goal of this study is to test the influence of the three independent variables, namely gender, education, and age, the participants were distributed into three groups as shown in Tables 1, 2, and 3 below.

The participants took part in this study voluntarily, and they were assured that their information will be kept anonymous and confidential. We avoided informing the participants of the specific purpose of the present study. After they consented, the test was distributed the. To put the participants' minds on ease over filling in the questionnaire, we asked them to produce the answers in the language and the script they preferred. We also assured them that any spelling mistakes were not problematic. Moreover, there was no time 
Table 1. Gender-based distribution of the participants

\begin{tabular}{lc}
\hline Gender & Number of participants \\
\hline Females & 50 \\
Males & 40 \\
\hline
\end{tabular}

Table 2. Education-based distribution of the participants

\begin{tabular}{lc}
\hline Educational level & Number of participants \\
\hline Educated & 40 \\
Uneducated & 50 \\
\hline
\end{tabular}

Table 3. Age-based distribution of the participants

\begin{tabular}{lc}
\hline Age & Number of participants \\
\hline Young $(15-45)$ & 50 \\
Old $(46-65+)$ & 40 \\
\hline
\end{tabular}

limit; the participants took as much time as needed. Most importantly, we avoided going near them or making them feel monitored while they were answering the questionnaire.

The reason behind doing all that was attempting as much as possible to eliminate all the possibilities that the 'Observer's Paradox' ${ }^{4}$ could take place. Hence, we could make sure that their answers were produced naturally and without any manipulation.

\section{The Test}

The test employed in this study consists of a questionnaire containing two sections: the first section aims at obtaining background information about the participants' gender, educational level, and age. The second section consists of two questions that test the participants' production of different loanwords (see Appendix A). The questions of the second section are written in Emirati Arabic and they aim to test the participants' productive skills (see also Zibin, 2016). These questions require one-word or two-word (e.g. compound words) answers. The first question requires the participants to identify the object that some pictures illustrate. The other question requires the participants to read some sentences written in Emirati Arabic, identify the items that the pictures illustrate, and fill in the blank with the words they usually use to refer to the illustrations.

\section{Research hypotheses}

The present study aims at corroborating the following hypotheses:

Hypothesis 1 (H1): there are statistically significant gender-based differences among speakers of EA regarding the use of loanwords.

Hypothesis $2(\mathrm{H} 2)$ : there are statistically significant education-based differences among speakers of EA regarding the use of loanwords.

Hypothesis 3 (H3): there are statistically significant agebased differences among speakers of EA regarding the use of loanwords.

\section{Statistical analysis}

In this study, a t-test employing the Statistical Package for Social Sciences (SPSS) was used to confirm or falsify the hypotheses formulated for the purpose of this study. This was done by demonstrating whether the differences between the participants' responses in terms of the independent variables, i.e. 'gender', 'education', and 'age' are statistically significant. Therefore, this test provides an answer as to whether these variables have an impact on the use of loanwords by speakers of EA. The next section presents and discusses the results of the current study.

\section{RESULTS AND DISCUSSION}

\section{Loanwords Used in Emirati Arabic}

In order to provide an answer to the first research question, which is concerned with the loanwords commonly used by Emirati speakers and with their origins, the questionnaires obtained from the participants were analysed; by checking the etymology of the loanwords used by the participants using The oxford English Dictionary (OED) and asking native speakers of the different languages from which the words were borrowed (Alahmadi, 2015). The results show that speakers of EA use loanwords of different origins like English, Persian, Hindi, and Turkish in addition to a few words of French, Italian, German, and Spanish origins. Table 4 below shows the different loanwords used by the participants, the way they pronounce them, and their origins.

Table 4. The loanwords, the way they are pronounced in Emirati Arabic, and their origins.

\section{Reasons behind the use of Loanwords by Speakers of EA}

As discussed in section 4.1., speakers of EA mostly use words of English, Persian, Turkish, and Hindi origins and a few words of French, Italian, German, and Spanish origins.

It is important to point out that the loanwords of French, Italian, German, and Spanish origins are used so widely not only by speakers of EA, but also by many people all over the world; these words become the first that everyone resorts to refer to what these words actually refer to. People do not even realise that these words are actually borrowed, as they have become fixed in their dialect. Maquillage, violino, pétrole, benzol, diesel, patata, villa, garage, pantalon, and hospital are examples of these words. In the test of this study, Although 6 items elicited French words responses, in real life, they are not used as frequently as words of English, Persian, Hindi, and Turkish words. Furthermore, words such as patata, pétrole, benzol, diesel, gas, gas cylinder, chai, and Facebook are used by speakers of EA because there are no Arabic equivalents to them, or as Hockett (1985) puts it, to fill a gap in the dialect. These loanwords refer to elements that were brought over to the UAE and were introduced in their original sense by merchants from other countries, and as a result of the Industrial Revolution that took place in Europe and left all the countries everywhere with no choice but to use these words in the sense they were first introduced. These words can be best described as 'foreign words' that 
Table 4. The loanwords, the way they are pronounced in Emirati Arabic, and their origins

\begin{tabular}{|c|c|c|c|}
\hline No. & Loanword & The way it is pronounced in EA & Its origin \\
\hline 1 & बाल्टी (Baaltee) (bucket) & [baldi] & Hindi \\
\hline 2 & charge & [tfard3] & English \\
\hline \multirow[t]{2}{*}{3} & 1- Boots & $1-[\mathrm{bu}: \mathrm{ts}]$ & 1- English \\
\hline & 2- जूते (joote) & $2-[\mathrm{d} z u: \mathrm{ti}]$ & 2- Hindi \\
\hline 4 & Çanta (bag) & {$[$ [ant'a $]$} & Turkish \\
\hline 5 & parfum (perfume) & [pa:rfa:m] & French \\
\hline \multirow[t]{2}{*}{6} & 1- çekiç & $1-\left[\int a: k u: \int\right]$ & 1- Turkish \\
\hline & 2- hammer & 2- [ha:mər] & 2- English \\
\hline \multirow[t]{2}{*}{7} & 1- maquillage & 1- [makja:d3] & 1- French \\
\hline & 2- make up & 2- [merk $\Lambda p]$ & 2- English \\
\hline \multirow[t]{2}{*}{8} & 1- gas & $1-[$ ва:z] & 1- English \\
\hline & 2- gas cylinder & 2- [slindər ва:z] & 2- English \\
\hline \multirow[t]{2}{*}{9} & 1- violino & 1- [faiəlın] & 1-Italian \\
\hline & كمانجه--2 (kamanja) (violin) & 2- [kama:n] & 2- Persian \\
\hline \multirow[t]{3}{*}{10} & 1- highlighter & 1- [hailaitər] & 1- English \\
\hline & 2- flowmaster & 2- [fləuma:stər] & 2- English \\
\hline & 3- marker & 3- [ma:rkər] & 3- English \\
\hline 11 & sandwich & [sandwi:f] & English \\
\hline 12 & cake & {$[\mathrm{k} 3: \mathrm{k}]$} & English \\
\hline 13 & cycle & [s3:kəl] & English \\
\hline 14 & cap & [Ka:p] & English \\
\hline 15 & bank & [bayk] & English \\
\hline 16 & ciment (cement) & [Isment] & French \\
\hline 17 & cupboard & {$[\mathrm{k} \wedge \mathrm{b} ə \mathrm{t}]$} & English \\
\hline \multirow[t]{2}{*}{18} & 1- glass & $1-[$ gla:s] & 1- English \\
\hline & 2- cup & $2-[\mathrm{Ku}: \mathrm{b}]$ & 2- English \\
\hline 19 & caffè (coffee) & {$[\mathrm{kpfi}]$} & Italian \\
\hline 20 & ice cream & [aIs kri: $\mathrm{m}]$ \& [Cas kri: $\mathrm{m}]$ & English \\
\hline 21 & freezer & [fri: zər] & English \\
\hline 22 & password & [pa:sw3:rd] & English \\
\hline \multirow[t]{2}{*}{23} & 1-برواز(burwaz) (frame) & 1- [bərwa:z] & 1- Persian \\
\hline & 2- frame & 2- [frs:m] & 2- English \\
\hline 24 & Power bank & [pavər bayk] & English \\
\hline \multirow[t]{2}{*}{25} & pink & [pınk] & English \\
\hline & 1- pétrole (petrol) & 1- [bətro:1] & 1- French \\
\hline \multirow[t]{2}{*}{26} & 2- benzol (benzene) & 2- [bənzi: $n]$ & 2- German \\
\hline & 3-diesel & 3- [di: zəl] & 3- German \\
\hline \multirow[t]{2}{*}{27} & 1- kese & $1-[\mathrm{ki}: \mathrm{s}]$ & 1- Turkish \\
\hline & 2-pack & 2- [pæk] & 2- English \\
\hline 28 & asker (soldier) & [Saskari] & Turkish \\
\hline 29 & stamp & [Sta:mp] & English \\
\hline \multirow[t]{2}{*}{30} & 1- دكان (dukan) (store) & 1- [duka:n] & 1- Persian \\
\hline & 2- supermarket & 2- [su: pərma:rkit] & 2- English \\
\hline \multirow[t]{2}{*}{31} & 1- chips & $1-\left[\int \mathrm{rbs}\right]$ & 1- English \\
\hline & 2- Patata (potato) & 2- [bata:təs] & 2- Spanish \\
\hline 32 & استاد (ostad) (teacher) & [əsta:ð] & Persian \\
\hline 33 & villa & [vilə] & Italian \\
\hline
\end{tabular}


Table 4. (Continued)

\begin{tabular}{|c|c|c|c|}
\hline No. & Loanword & The way it is pronounced in EA & Its origin \\
\hline 34 & license & [l3:sən] & English \\
\hline 35 & eyeliner & [as lainər] & English \\
\hline 36 & cover & {$[\mathrm{k} \Lambda$ vər $] \&[\mathrm{kavər}]$} & English \\
\hline \multirow[t]{2}{*}{37} & 1- garage & $1-[$ kara:d3] & 1- French \\
\hline & 2-parking & 2- [ba:rkın] & 2- English \\
\hline 38 & share location & 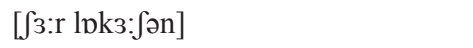 & English \\
\hline 39 & सीधे (seedhe) (straight) & [si: da] & Hindi \\
\hline 40 & جاى (chai) (tea) & [tfar] \& [tfa:hi] & Persian \\
\hline 41 & security & [səkjorəti] & English \\
\hline \multirow[t]{2}{*}{42} & 1- pantalon (trousers) & 1- [bant $\left.t^{\varsigma} a l \supset: n\right]$ & 1- French \\
\hline & 2- شلو ار (Shilwar) (trousers) & 2- [sirwa:1] & 2- Persian \\
\hline 43 & goal & [go:1] & English \\
\hline \multirow[t]{2}{*}{44} & 1- laptop & 1- [læbtpp] & 1- English \\
\hline & 2- computer & 2- [kpmbju: tər] & 2- English \\
\hline \multirow[t]{2}{*}{45} & 1- hospital & 1 - [estrbalıa] & 1- English \\
\hline & 2- doctor & 2- [daXtər] & 2- English \\
\hline 46 & doctor & [dəkto:r] \& [daXtər] & English \\
\hline 47 & cream & [Kri: m] & English \\
\hline 48 & shovel & {$\left[\int 3: \mathrm{wəl}\right]$} & English \\
\hline \multirow[t]{2}{*}{49} & 1- hose & 1- [ho:z] and [fo:z] & 1- English \\
\hline & 2- pipe & 2- [bi: b] and [barb] & 2- English \\
\hline 50 & Facebook & [fersbuk] & English \\
\hline
\end{tabular}

Emiratis have started using after they have been phonologically adapted. For example, gas has been pronounced as ghaаz [ва:z], and pétrole has been pronounced as bitrol [bətro:1]. In addition, some Arabic equivalents of loanwords are compounds of more than 3 syllables such as masaahiq t-tajmil [masæhi: q t-tadzmi: 1] 'make up' and qalam takhtiit [qalam taXti $\mathrm{t}^{\mathrm{i}} \mathrm{t}^{\mathrm{c}}$ ] 'marker' (see Altakhaineh, 2016; Altakhaineh 2017). Hence, speakers of EA would prefer to be economic and use loanwords such as make up or maquillage and marker that are shorter than their Arabic equivalents.

In the UAE, various Arabic dialects, languages, and many hybrids and distinct pidgins of Arabic, Asian, and Anglo-American have been identified (Mazid, 2006). Interestingly, the UAE is a home for more than 200 nationalities. Locals constitute one fourth of the population of the UAE, which means most of the encounters involve expatriates (Mazid, 2006). As a matter of fact, the Indian expatriate community is the largest one in the UAE. No one can deny the bilateral relations between the two countries in terms of oil and non-oil trade and the influence of Indian culture on many aspects of life in the UAE such as food, clothes, and different tools. Inevitably, words of Hindi origins such as seedhe (straight), jooti (shoes), and baaltee (bucket) have found their way into Emirati Arabic.

Similarly, Iran and the UAE are bound to have close cultural relationships due to the geography that makes it easy for such relations; the two countries are on opposite sides of the Arabian Gulf. Iranians, be they traders, investors, or normal residents, have their significant community and famous social club in the UAE, namely, 'The Iranian Club Dubai'. Hence, they have had their long-standing cultural influence, especially language, over the UAE society given the historical commercial relationships.

With regard to the Turkish loanwords, speakers of EA have started to acquire some Turkish words as a result of mingling with residents from the Levant who themselves were influenced by the Ottoman Turkish under the Ottoman Empire. In addition, the trend today in the Arab world, especially in the UAE, is Turkish movies and series, whether they are subtitled or dubbed by people from the Levant. Consequently, speakers of EA have started using easy Turkish daily-life words such as Çanta (bag), Çekiç (hammer), kese (pack), and asker (soldier).

With respect to the English loanwords, despite not having been integrated in EA as early as Persian, Hindi, and Turkish loanwords have been, they constitute the highest number of all loanwords found in EA. Many important factors have led to this; first, the English language has started to be taught in schools since the UAE was under the British power in the $19^{\text {th }}$ century. Second, After the UAE was formed as an independent country in 1971 (Martin, 2003) and after the discovery of oil, transformation in different dimensions in the country dramatically happened. For instance, workers in various fields of medicine, teaching, and business who mostly spoke English as a lingua franca were imported to the UAE (Hopkyns, 2014). They now outnumber the native population; Emiratis make up less than $20 \%$ of the population (Findlow, 2006). As a result, English in the UAE has 
become the norm in formal and non-formal domains of leisure, tourism, and daily life (Hopkyns. 2014). As a result, EA contains numerous English words in so many aspects of life to the extent that Emiratis, as they have been obsereved, would include 1 to 2 English loanwords, whether adopted or adapted, in most of the sentences they say. Table 4 in section 4.1 shows many English loanwords encountered in EA. The next section examines the study hypotheses and provides an answer to the third research question.

\section{The Impact of Gender, Education, and Age on the use of loanwords by speakers of EA}

This section examines the hypotheses formulated for this study and provides an answer to the third research question, which is concerned with whether the gender, the educational level, and the age of speakers of EA has an impact on their

Table 5. Results of t-test of positive responses in terms of gender

\begin{tabular}{lccccc}
\hline Gender & Number & Mean & T value & $\begin{array}{c}\text { Degree of } \\
\text { freedom }\end{array}$ & Sig. \\
\hline Females & 50 & 85 & 3.900 & 49 & $0.000^{*}$ \\
Males & 40 & 65 & & & \\
\hline${ }^{*} \mathrm{p}<0.05$ & & & & & \\
\end{tabular}

use of these words and how. This is achieved by discussing the results of the t-test conducted in this study and the percentages of the positive responses ${ }^{7}$ regarding each variable.

\section{Gender}

Starting with the gender variable, Table 5 below shows the results of the t-test conducted to test the first hypothesis $\mathrm{H} 1$.

A careful examination of Table 5 shows that $p$ value is lower than 0.05 , which means that there were statistically significant differences between the responses of females and males, in other words, H1 was confirmed. This table also answers the first part of the third research question by comparing the means of the both parties ( $85 \%$ and $65 \%$ for female participants and male ones, respectively): yes, the gender of EA speakers has an impact on their use of loanwords; females used loanwords more than males. For more information regarding the results obtained from the gender group, Table 6 below provides a detailed analysis of the results obtained from the participants, presenting the percentages of the loanwords provided for each item in the test regardless of the words origins.

As shown in Table 6, female speakers if EA (85\%) use loanwords more than males $(65 \%)$. A main reason for this result is that Emirati females usually seek modernity and prestige, even in their speech. Hence, they would use English

Table 6. The percentages of the positive responses in terms of gender

\begin{tabular}{|c|c|c|c|c|c|}
\hline \multirow[t]{2}{*}{ Loanword } & & & \multicolumn{2}{|c|}{ Percentage } & \multirow[t]{2}{*}{ Mean of total responses $\%$} \\
\hline & & & Females & Males & \\
\hline baaltee & & & 35 & 28 & 32 \\
\hline charge & & & 75 & 55 & 65 \\
\hline 1- boots & 2-joote & & 100 & 70 & 85 \\
\hline Çanta & & & 100 & 100 & 100 \\
\hline parfum & & & 63 & 0 & 32 \\
\hline 1- çekiç & 2- hammer & & 80 & 25 & 53 \\
\hline 1- maquillage & 2- make up & & 100 & 100 & 100 \\
\hline 1- gas & 2- gas cylinder & & 100 & 100 & 100 \\
\hline 1- violino & 2- kamanja & & 88 & 75 & 82 \\
\hline 1- highlighter & 2- flowmaster & 3- marker & 75 & 70 & 73 \\
\hline sandwich & & & 100 & 100 & 100 \\
\hline cake & & & 100 & 75 & 88 \\
\hline cycle & & & 85 & 100 & 93 \\
\hline cap & & & 85 & 75 & 80 \\
\hline bank & & & 100 & 100 & 100 \\
\hline ciment & & & 75 & 88 & 82 \\
\hline cupboard & & & 88 & 55 & 72 \\
\hline 1- glass & 2- cup & & 100 & 100 & 100 \\
\hline caffè & & & 60 & 0 & 30 \\
\hline ice cream & & & 100 & 100 & 100 \\
\hline freezer & & & 75 & 25 & 50 \\
\hline password & & & 75 & 30 & 53 \\
\hline burwaz & & & 83 & 25 & 54 \\
\hline
\end{tabular}


Table 6. (Continued)

\begin{tabular}{|c|c|c|c|c|c|}
\hline \multirow[t]{2}{*}{ Loanword } & & & \multicolumn{2}{|c|}{ Percentage } & \multirow[t]{2}{*}{ Mean of total responses $\%$} \\
\hline & & & Females & Males & \\
\hline power bank & & & 75 & 55 & 65 \\
\hline pink & & & 55 & 0 & 28 \\
\hline 1- pétrole & 2- benzol & 3- diesel & 100 & 100 & 100 \\
\hline 1- kese & 2-pack & & 100 & 100 & 100 \\
\hline asker & & & 65 & 25 & 45 \\
\hline stamp & & & 55 & 25 & 40 \\
\hline 1- dukan & 2- supermarket & & 75 & 80 & 78 \\
\hline 1- chips & 2-patata & & 100 & 100 & 100 \\
\hline ostad & & & 88 & 75 & 82 \\
\hline villa & & & 95 & 75 & 85 \\
\hline license & & & 88 & 75 & 82 \\
\hline eyeliner & & & 95 & 18 & 57 \\
\hline cover & & & 88 & 75 & 82 \\
\hline 1- garage & 2-parking & & 100 & 85 & 93 \\
\hline share location & & & 63 & 58 & 61 \\
\hline seedhe & & & 100 & 100 & 100 \\
\hline chai & & & 100 & 100 & 100 \\
\hline security & & & 83 & 43 & 63 \\
\hline 1- pantalon & 2- shilwar & & 100 & 58 & 79 \\
\hline goal & & & 88 & 83 & 86 \\
\hline 1- laptop & 2- computer & & 88 & 80 & 84 \\
\hline 1- hospital & 2- doctor & & 65 & 13 & 39 \\
\hline doctor & & & 83 & 63 & 73 \\
\hline cream & & & 88 & 28 & 58 \\
\hline shovel & & & 100 & 100 & 100 \\
\hline 1- hose & 2- pipe & & 83 & 63 & 73 \\
\hline Facebook & & & 100 & 100 & 100 \\
\hline Mean of total responses \% & & & 85 & 65 & 75 \\
\hline
\end{tabular}

loanwords more than any other words of other origins because, to them, English is the modern and the prestigious language. This particular result supports the results of Al Btoush (2014), in terms of gender; he found that Jordanian females' positive responses outnumbered those of the males, as they find using English prestigious. This is due to the fact that English is the international language, and high-class people know more than one language. Emirati Males, on the other hand, tend to use more of Hindi and Persian loanwords; since they are not usually after being prestigious, they use more of the words that they were born to, without realising that these words were actually borrowed. Female speakers of EA would refer to frame, which is a border surrounding a picture, as frame, while males would refer to it as burwaz, the Persian equivalent of frame, or by using the Arabic equivalent of it (i.e., Itaar [It $\left.\left.{ }^{\uparrow} a: r\right]\right)$, for example.

\section{Education}

Moving on to the second variable, education, Table 7 below presents the results of the t-test conducted to examine the second hypothesis $\mathrm{H} 2$.
Table 7. Results of t-test of positive responses in terms of education

\begin{tabular}{lccccc}
\hline Education & Number & Mean & T value & $\begin{array}{c}\text { Degree of } \\
\text { freedom }\end{array}$ & Sig. \\
\hline Educated & 40 & 76 & 2.487 & 49 & $0.015^{*}$ \\
Uneducated & 50 & 61 & & & \\
\hline$* \mathrm{p}<0.005$ & & & & & \\
\hline
\end{tabular}

Table 7 above demonstrates that $\mathrm{H} 2$ was also confirmed; there were statistically significant differences between the responses of the educated and the uneducated participants, as the $\mathrm{p}$ value is lower than 0.05 . Moreover, comparing the means of the educated participants $(76 \%)$ and uneducated ones $(61 \%)$ provides an answer to the second part of the third research question, that is, the educational level of speakers of EA does have an impact on their use of loanwords; the educated participants used loanwords more the uneducated ones.

Table 8 below provides a detailed analysis of the results obtained from the participants in the education group by 
Table 8. The percentages of the positive responses in terms of education

\begin{tabular}{|c|c|c|c|c|c|}
\hline \multirow[t]{2}{*}{ Loanword } & & & \multicolumn{2}{|c|}{ Percentage } & \multirow[t]{2}{*}{ Mean of total responses $\%$} \\
\hline & & & Educated & Uneducated & \\
\hline baaltee & & & 20 & 37 & 29 \\
\hline charge & & & 86 & 77 & 82 \\
\hline 1 - boots & 2-joote & & 86 & 80 & 83 \\
\hline Çanta & & & 100 & 100 & 100 \\
\hline parfum & & & 71 & 0 & 36 \\
\hline 1- çekiç & 2- hammer & & 43 & 14 & 29 \\
\hline 1- maquillage & 2- make up & & 100 & 100 & 100 \\
\hline 1- gas & 2- gas cylinder & & 100 & 100 & 100 \\
\hline 1- violino & 2- kamanja & & 100 & 80 & 90 \\
\hline 1- highlighter & 2- flowmaster & 3- marker & 51 & 34 & 43 \\
\hline Sandwich & & & 100 & 100 & 100 \\
\hline cake & & & 100 & 100 & 100 \\
\hline cycle & & & 80 & 100 & 90 \\
\hline cap & & & 54 & 20 & 37 \\
\hline cank & & & 100 & 100 & 100 \\
\hline ciment & & & 57 & 23 & 40 \\
\hline cupboard & & & 54 & 51 & 53 \\
\hline 1- glass & 2- cup & & 100 & 80 & 90 \\
\hline caffè & & & 37 & 20 & 29 \\
\hline ice cream & & & 100 & 100 & 100 \\
\hline freezer & & & 57 & 17 & 37 \\
\hline password & & & 51 & 34 & 43 \\
\hline 1- burwaz & 2- frame & & 67 & 43 & 55 \\
\hline power bank & & & 57 & 34 & 46 \\
\hline pink & & & 37 & 0 & 19 \\
\hline 1- pétrole & 2- benzol & 3-diesel & 100 & 100 & 100 \\
\hline 1- kese & 2-pack & & 100 & 100 & 100 \\
\hline asker & & & 71 & 86 & 79 \\
\hline stamp & & & 34 & 0 & 17 \\
\hline 1- dukan & 2- supermarket & & 80 & 77 & 79 \\
\hline 1- chips & 2- potato & & 100 & 100 & 100 \\
\hline ostad & & & 23 & 77 & 50 \\
\hline villa & & & 66 & 60 & 63 \\
\hline license & & & 63 & 77 & 70 \\
\hline eyeliner & & & 88 & 17 & 53 \\
\hline cover & & & 83 & 40 & 62 \\
\hline 1- garage & 2- parking & & 100 & 65 & 83 \\
\hline share location & & & 90 & 52 & 71 \\
\hline seedhe & & & 100 & 100 & 100 \\
\hline chai & & & 100 & 100 & 100 \\
\hline security & & & 87 & 45 & 66 \\
\hline 1- pantalon & 2- shilwar & & 96 & 56 & 76 \\
\hline goal & & & 92 & 67 & 80 \\
\hline 1- laptop & 2- computer & & 88 & 65 & 77 \\
\hline 1- hospital & 2- doctor & & 56 & 77 & 67 \\
\hline doctor & & & 70 & 76 & 73 \\
\hline
\end{tabular}


Table 8. (Continued)

\begin{tabular}{lcccc}
\hline Loanword & \multicolumn{2}{c}{ Percentage } & Mean of total responses \% \\
\cline { 2 - 4 } & Educated & Uneducated & \\
\hline cream & 90 & 44 & 100 & 100 \\
shovel & 2- pipe & 100 & 75 & 82 \\
1- hose & & 88 & 100 & 100 \\
Facebook & 100 & 68 & 78 \\
Mean of total responses \% & 88 & & \\
\hline
\end{tabular}

showing the percentages of the positive responses for each item in the test regardless of loanwords origins.

Table 8 above shows that the educated speakers of EA (76\%) use loanwords more than the uneducated ones $(61 \%)$. It is important to mention that the classification we followed in terms of education was based on having the university degree (Alotaibi, 2015); those who have obtained it were considered educated, and those who have not were considered uneducated. The positive responses of the educated speakers of EA are, to a great extent, of English loanwords, and that came as no surprise because they study English as a second language at school and college where, as Krashen (1989) maintains with regard to his Input Hypothesis, communicative and comprehensible input is supplied to students so that they would acquire spelling and vocabulary and of the second language. Furthermore, it seems that the language system speakers of EA set for their communication devices like mobile phones is English. Hence, they would unconsciously acquire words in the area of technology and start using them; especially most Emiratis are very much into using technological devices these days. For instance, the item number 38 in the questionnaire required responses regarding 'sharing location' in 'What's app', a social media phone application. Most of the educated participants responded with share location. Others used words of the Modern Standard Arabic (MSA) such as irsaal mawqi [Irsæl mavqIS]. The educated participants' responses were a mix of loanwords and words of MSA. Using MSA is a mark of the educated person in the Arab world and is considered prestigious (Alahmadi, 2015). It can be noticed that, despite the significant differences between the positive responses of the educated participants and the uneducated ones, the total average of the responses of the uneducated participants $(61 \%)$ was above $50 \%$, but the responses were more of Persian, Hindi, and Turkish loanwords, and less of English loanwords. Since the uneducated speakers of EA are not exposed to and are not using English as much as the educated ones, their use of English loanwords is less than that of the educated ones. However, they would still use some words like ice cream, Facebook, cake, cycle, bank, sandwich, and shovel unconsciously and after phonologically adapting them. This is basically because these words have been passed on and used in their sense not only among Emiratis but also among other people from other nationalities notwithstanding their Arabic equivalents, except for Facebook. This word does not have an Arabic equivalent, so it has entered their modern lexicon and has been used as it is.
Table 9. Results of t-test of positive responses in terms of age

\begin{tabular}{lccccc}
\hline Age & Number & Mean & T value & $\begin{array}{c}\text { Degree of } \\
\text { freedom }\end{array}$ & Sig. \\
\hline Younger & 50 & 88 & 4.770 & 49 & $0.000^{*}$ \\
Older & 40 & 68 & & & \\
\hline
\end{tabular}

$* \mathrm{p}<0.05$

\section{Age}

A t-test was conducted to examine the third hypothesis H3, which is concerned with age. These results are reported in Table 9 below.

Table 9 shows that $\mathrm{H} 3$ was confirmed as well; the $\mathrm{p}$ value is lower than 0.05 , that is, there were statistically significant differences between the responses of the younger and the older participants. the table also shows that the younger participants $(88 \%)$ used loanwords more than the older ones $(68 \%)$, which suggests a positive answer for the third part of the third research question, proposing that the age of speakers of EA does have an impact on their use of loanwords.

Table 10 below presents the percentages of the loanwords provided by the participants in the age group for each item in the test regardless of the words origins.

A study of Table 10 reveals that the young participants used loanwords more than the old ones. Nowadays, many younger speakers of EA are eager to learn new languages. To show that they have knowledge of languages other than Arabic, in other words, to show off, they would integrate what they have picked up and acquired from other languages in their daily life communication. Furthermore, younger speakers of EA usually keep up-to-date with the new terms of other languages regarding technology, food, clothes, education, health, and cosmetics; especially those of English origins. This is because English is the trend of the day; it is attached to modernity and globalisation (Zenner, Speelman \& Geeraerts, 2013). This specific result goes hand in hand with Alahmadi's (2015), which states that younger speakers of UMH prefer to use English loanwords, as English is prestigious and modern. In contrast, older ones would use more of Persian and Hindi words, as these words have appeared earlier than English in EA. Therefore, older speakers of EA are accustomed to using them for a quite long time. They would not prefer to deliberately use words of English origins, for example, to change their speech style; they would stick to the language that was at the height of their time and 
Table 10. The percentages of the positive responses in terms of age

\begin{tabular}{|c|c|c|c|c|c|c|}
\hline \multirow[t]{2}{*}{ Loanword } & & & & \multicolumn{2}{|c|}{ Percentage } & \multirow[t]{2}{*}{ Mean of total responses $\%$} \\
\hline & & & & Younger & Older & \\
\hline baaltee & & & & 65 & 77 & 71 \\
\hline charge & & & & 88 & 65 & 77 \\
\hline 1- Boots & & 2-joote & & 95 & 65 & 80 \\
\hline Çanta & & & & 100 & 100 & 100 \\
\hline parfum & & & & 77 & 45 & 61 \\
\hline 1- çekiç & & 2- hammer & & 77 & 71 & 74 \\
\hline 1- maquillage & & 2- make up & & 100 & 100 & 100 \\
\hline 1- gas & & 2- gas cylinder & & 100 & 100 & 100 \\
\hline 1- violino & & 2- kamanja & 3- marker & 100 & 80 & 90 \\
\hline 1- highlighter & & 2- flowmaster & & 85 & 50 & 68 \\
\hline sandwich & & & & 100 & 100 & 100 \\
\hline cake & & & & 100 & 75 & 88 \\
\hline cycle & & & & 85 & 75 & 80 \\
\hline cap & & & & 77 & 56 & 67 \\
\hline bank & & & & 100 & 100 & 100 \\
\hline ciment & & & & 88 & 55 & 72 \\
\hline cupboard & & & & 88 & 65 & 77 \\
\hline 1- glass & & 2- cup & & 100 & 80 & 90 \\
\hline caffè & & & & 55 & 12 & 34 \\
\hline ice cream & & & & 100 & 100 & 100 \\
\hline freezer & & & & 92 & 35 & 64 \\
\hline password & & & & 90 & 56 & 73 \\
\hline 1- burwaz & & 2- frame & & 75 & 35 & 55 \\
\hline power bank & & & & 88 & 25 & 57 \\
\hline pink & & & & 85 & 14 & 50 \\
\hline 1- pétrole & 2- benzol & 3-diese & & 100 & 100 & 100 \\
\hline 1- kese & & 2-pack & & 100 & 100 & 100 \\
\hline asker & & & & 56 & 85 & 71 \\
\hline stamp & & & & 67 & 10 & 39 \\
\hline 1- dukan & & 2- supermarket & & 88 & 55 & 72 \\
\hline 1- chips & & 2- potato & & 100 & 100 & 100 \\
\hline ostad & & & & 55 & 75 & 65 \\
\hline villa & & & & 90 & 65 & 78 \\
\hline license & & & & 92 & 80 & 86 \\
\hline eyeliner & & & & 88 & 25 & 57 \\
\hline cover & & & & 83 & 45 & 64 \\
\hline 1- garage & 2-parking & & & 100 & 65 & 83 \\
\hline share location & & & & 90 & 52 & 71 \\
\hline seedhe & & & & 100 & 100 & 100 \\
\hline chai & & & & 100 & 100 & 100 \\
\hline security & & & & 87 & 45 & 66 \\
\hline 1- pantalon & 2-shilwar & & & 96 & 56 & 76 \\
\hline goal & & & & 92 & 67 & 80 \\
\hline 1- laptop & 2-computer & & & 88 & 65 & 77 \\
\hline 1- hospital & 2-doctor & & & 56 & 77 & 67 \\
\hline doctor & & & & 70 & 76 & 73 \\
\hline
\end{tabular}


Table 10. (Continued)

\begin{tabular}{lccc}
\hline \multirow{2}{*}{ Loanword } & \multicolumn{2}{c}{ Percentage } & Mean of total responses \% \\
\cline { 2 - 4 } & Younger & Older & 67 \\
\hline cream & 90 & 44 & 100 \\
shovel & 100 & 100 & 82 \\
1 - hose & 88 & 75 & 100 \\
facebook & 100 & 100 & 78 \\
Mean of total & 88 & 68 & \\
responses \% & & & \\
\hline
\end{tabular}

that they were born to and have lived with. In addition, older speakers of EA do not have much contact with English as younger speakers of EA do. In addition, they would not normally care to learn a new language and pay attention to the updates in their dialect.

\section{CONCLUSION AND RECOMMENDATIONS}

To sum up, this study found that speakers of EA use loanwords of different origins but mostly of English, Persian, Hindi, and Turkish ones. English has been incorporated in EA because the UAE was under the British mandate in the $19^{\text {th }}$ century and as a result of importing workers who speak English as a lingua franca to the area after the discovery of oil. Hindi loanwords have been used due to the bilateral ties between the UAE and India, as a result, Indians now have their own linguistic influence on EA. Persian loanwords have found their way into EA due to the commercial relationships between the UAE and Iran, and that, in turn, facilitated the contact between the two languages. Turkish has been used by Emiratis as a result of mingling with Levantines who were influenced by Ottoman Turkish and by watching Turkish TV programs.

With regard to gender, the study shows that there were statistically significant differences between female and male participants regarding the use of loanwords. It also demonstrates that female speakers of EA use loanwords, especially words of English origins, more than their male counterparts because the former usually seek prestige even in their speech. Male speakers of EA, on the other hand, use more of Persian and Hindi loanwords and are not usually aware that these were actually borrowed. In terms of the educational level, there were statistically significant differences between the educated and the uneducated participants. Educated speakers of EA use loanwords more than the uneducated ones, and they mostly use English words since they have more contact with English. Conversely, uneducated speakers of EA would use more Persian, Hindi, and Turkish words than English ones. Regarding age, the results demonstrate that there were statistically significant differences between the young and old participants regarding using loanwords. Younger speakers of EA exhibit readiness to learn new languages, especially English, as it is the language of the day while older ones would use more Persian and Hindi words because these words have appeared early in EA, so older speakers of EA prefer to use words they were born to and have lived with.
Finally, it is recommended that the phonological adaptation and morphological alternations that loanwords in EA undergo and the reasons behind these processes be investigated to obtain a better understanding of EA and the phenomenon of loanwords. In addition, the results of this study; especially the ones pertaining to the use of English loanwords, strongly support Altakhaineh and Rahrouh's (2017) call for further research to investigate the use of and attitudes towards English in the UAE. Moreover, it seems that the way gender influences the use of loanwords is still somehow inexplicit. It is evident that Emirati males and females use language differently, and it is reasonable to say that females have more positive attitudes towards using loanwords in their regular speech. However, further research is needed to support that claim and the ways by which gender, as a social variable, influences the use of loanwords.

\section{ACKNOWLEDGMENT}

We would like to thank Dr Abdel Rahman Mitib Altakhaineh for his comments on early drafts of the paper. We are also grateful to Eiman Al- Kaabi, an Emirati student in Al Ain University for her help in wording the sentences of the questionnaire in Emirati Arabic.

\section{END NOTES}

1 According to Webster's New World Dictionary, a bobby soxer, especially in the 1940's, was a girl in her early teens who conformed to adolescent fads.

2 According to Webster's New World Dictionary, an idiolect is the way one person uses language. It is smaller than a dialect which is the way a group of people speak in a region, and hence, differs from a region to another.

3 Faculty, in this context, refers to university department.

4 The observer's paradox refers to situations when the presence of the researcher unwittingly influences the results of the study just by being around people being observed. This term was coined by William Labov (1972, p.209) who stated that "the aim of linguistic research in the community must be to find out how people talk when they are not being systematically observed; yet we can only obtain these data by systematic observation."

5 The word ciment is originally Latin.

6 The word hospital is originally Latin

7 Positive responses in this study are the responses that included loanwords. 


\section{REFERENCES}

Al Btoush, M. A. (2014). English Loanwords in Colloquial Jordanian Arabic. International Journal of Linguistics, 6(2), 98. http://dx.doi.org/10.17507/jltr.0702.06

Alahmadi, S. D. (2015). Loanwords in the Urban Meccan Hijazi Dialect: An Analysis of Lexical Variation according to Speakers' Sex, Age and Education. International Journal of English Linguistics, 5(6), 34. Retrieved on $23^{\text {rd }}$ August 2017 from http://dx.doi.org/10.5539/ijel. v5n6p34

Alnamer, S. A. S. (2017). On the Awareness of English Polysemous Words by Arabic-Speaking EFL Learners. Advances in Language and Literary Studies, 8(2), 112-121 Retrieved on $25^{\text {th }}$ September 2017 from http://dx.doi. org/10.7575/aiac.alls.v.8n.2p.112

Alotaibi, A. M. (2015). The awareness of euphemism by Kuwaiti speakers of Arabic. International Journal of Linguistics, 7(1), 69-81. http://dx.doi.org/10.5296/ijl. v7i1.6428

Al-Saidat, E. (2011). English Loanwords in Jordanian Arabic: Gender and number Assignment. In Language Forum (Vol. 37, No. 1, 59-72).

Altakhaineh, A. R. M. (2016). Identifying Arabic compounds other than the Synthetic Genitive Construction. Acta Linguistica Hungarica, 63(3), 277-298. http://dx. doi.org/10.1556/064.2016.63.3.1

Altakhaineh, A. R. M. (2017). Arabic Compounds within the Cross-Linguistic Compound Taxonomy of Scalise and Bisetto (2009). Lingue e linguaggio, 16(1). 101-118.

Altakhaineh, A. R. M., \& Rahrouh, H. N. (2015). The use of euphemistic expressions by Arab EFL learners: Evidence from Al Ain University of Science and Technology. International Journal of English Linguistics, 5(1), 14. http://dx.doi.org/10.5539/ijel.v5n1p14

Altakhaineh, A. R. M., \& Rahrouh, H. N. (2017). Language Attitudes: Emirati Perspectives on the Emirati Dialect of Arabic According to Age and Gender. The Social Sciences, 12(8), 1434-1439.

Baker, C. (1995). Attitudes and language. Clevedon, UK: Multilingual Matters.

Berg, S. (1988). Snowball sampling-I. Encyclopedia of statistical sciences.

Chambers, J. (2009). Sociolinguistic theory. Singapore: Utopia Press Pte Ltd.

Eckert, P. (1998). In Coulmas, F. (ed), The handbook of sociolinguistics. Blackwell Publishing.

Findlow, S. (2006). Higher education and linguistic dualism in the Arab Gulf. British Journal of Sociology of Education, 27(1), 19-36. Retrieved on $23^{\text {rd }}$ November 2017 from https://doi.org/10.1080/01425690500376754

Giddens, A. (1989) Sociology. Cambridge: Polity Press

Gramley, S. (2001). The Vocabulary of World English. London: Arnold.

Haspelmath, M. (2009). Lexical borrowing: Concepts and issues. Loanwords in the world's languages: A comparative handbook, 35-54.

Haspelmath, M., \& Tadmor, U. (Eds.). (2009). Loanwords in the world's languages: a comparative handbook. Walter de Gruyter.
Hockett, C. F. (1958). A course in modern linguistics. Language Learning, 8(3-4), 73-75.

Hoffer, B. L. (2002). Language borrowing and language diffusion: An overview. Intercultural communication studies, $9(2), 1-36$.

Hoffer, B. L. (2005). Language borrowing and the indices of adaptability and receptivity. Intercultural communication studies, 14(2), 53.

Hopkyns, S. (2014). The effect of global English on culture and identity in the UAE: a double-edged sword. Learning and Teaching in Higher Education: Gulf Perspectives, 11(2). Retrieved on $12^{\text {th }}$ November 2017 from http://dx.doi.org/10.18538/lthe.v11.n2.197

Hugar, S. (1982). The effect of gender on first and second language use and acquisition. Applied linguistic. $21,17-31$.

Kang, Y. (2011). Loanword phonology. The Blackwell companion to phonology, 4, 1003-1026.

Kistler, S. A. (2005). Loanwords and Code-switching: Distinguishing Between Language Contact Phenomena in Ch'ol. Alternate Routes: A Journal of Critical Social Research, 21.

Koka, N. A. (2014). A sociolinguistic investigation of social stratification and linguistic variation among the Kashmiri speech community. Journal of Language Teaching and Research, 5(5), 1071-1084. Retrieved on 12 $2^{\text {th }}$ August 2017 from http://dx.doi.org/10.4304/ jltr.5.5.1071-1084

Krashen, S. (1989). We acquire vocabulary and spelling by reading: Additional evidence for the input hypothesis. The modern language journal, 73(4), 440-464.

Kuitert, S. R. (2013). English Loanwords in Norwegian: A Loanword Processing Study in Young Speakers of Norwegian (Master's thesis, Norges teknisk-naturvitenskapelige universitet, Det humanistiske fakultet, Institutt for moderne fremmedspråk).

Labov, W. (1972). Sociolinguistic Patterns. Philadelphia: University of Pennsylvania Press.

Martin, A. (2003). An experience of teaching in the United Arab Emirates. English Today, 19(2), 49-54.

Mazid, B. E. M. (2006). (Translating) Emirati Arabic Politeness Formulas: An exploratory study and a mini-mini-dictionary.

Myers-Scotton, C. (2002). Contact linguistics: Bilingual encounters and grammatical outcomes. Oxford University Press on Demand.

Owens, J., Dodsworth, R., \& Kohn, M. (2013). Subject expression and discourse embeddedness in Emirati Arabic. Language Variation and Change, 25(3), 255-28. https://doi.org/10.1017/S0954394513000173

Robins, R. H. (1964) General Linguistics: Introductory Survey. London: Longmans.

Romaine, S. (2000). Language in society: An introduction to sociolinguistics. Oxford University Press.

Simpson. J.A and E.S.C. Weiner (Eds.). (1989). The Oxford English Dictionary. Second edition. Oxford: Oxford University Press.

Trudgill, P. (1972). The Social Differentiation of English in Norwich. Cambridge: Cambridge University Press. 
Uffmann, C. (2006). Epenthetic vowel quality in loanwords: Empirical and formal issues. Lingua, 116(7), 1079-1111.

Van Der Sijs, N. (2005). Van Dale Groot Leenwoordenboek. Utrecht/Antwerpen: Van Dale Lexicografie.

Vegt, W. V. D. (2014). Attitudes towards English Loanwords in Dutch News Broadcasts: The Influence of Gender and Age (Master's thesis).

Victoria, N., \& Guralnik, D. B. (1988). Webster's New World Dictionary, Third College Edition.
Zenner, E., Speelman, D., \& Geeraerts, D. (2013). Macro and micro perspectives on the distribution of English in Dutch: A quantitative usage-based analysis of job ads. https://doi.org/10.1515/ling-2013-0036.

Zibin, A. (2016). On the production of metaphors and metonymies by Jordanian EFL learners: Acquisition and implications. Topics in Linguistics, 17(2), 41-58. https:// doi.org/10.1515/topling-2016-0012. 


\section{APPENDIX}

\section{Appendix A: The translated version of the questionnaire (English version).}

Dear respected ladies and gentlemen,

We, the authors, are currently conducting a study regarding the Emirati dialect. Hence, we are kindly asking you to take a part in this study by answering the questions listed below in this questionnaire given that we are taking the confidentiality of your information upon us. For more information, you can contact us via $=$ the email mentioned below.

Best regards,

Abdul Salam Alnamer \& Sulafah Al Namer

Email: sulafah57@gmail.com

Phone number: 00971506015746

Section 1: general information about the participants

The questions of this section are to be answered by circling the appropriate answer.

1) Gender

Male

Female

2) Education

Holding a university degree

Not holding a university degree

3) Age

Please mention your age

Section two: the questions of the study

This section is of two questions.

1) The first question is to be answered by identifying the illustrations in the pictures.

2) The second question is to be answered by reading sentences that are describing some pictures and filling in the blank

Question 1: what do you call these things?
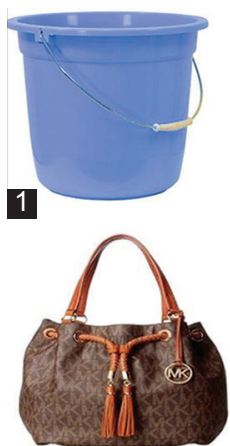

4

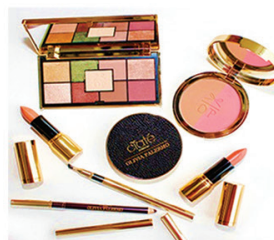

7

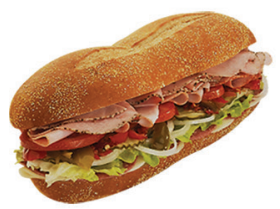

10

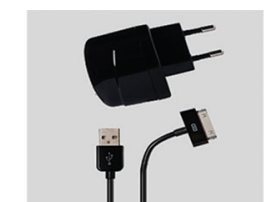

2

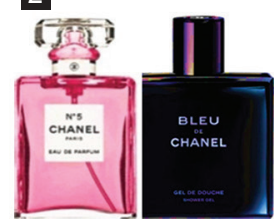

5

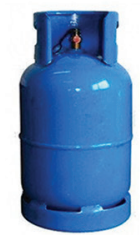

8

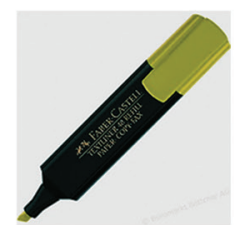

11
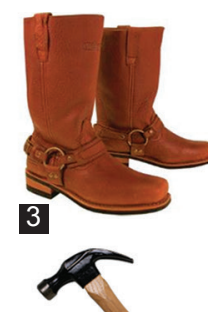

6

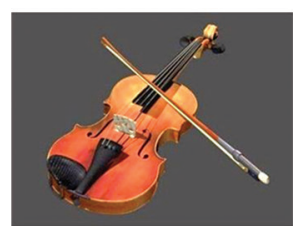

9

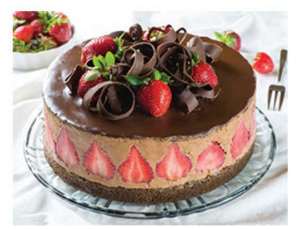

12
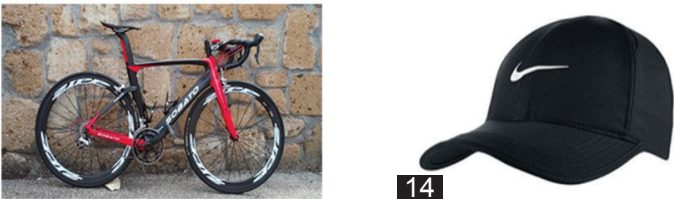
Question 2: there is a picture beside every sentence. Please fill in the blank with what each picture illustrates.

15- If you want any financial help, you can go to the

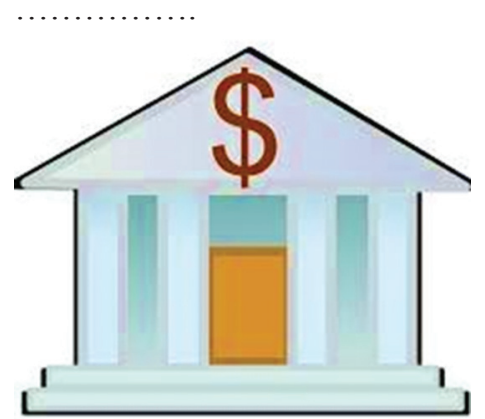

16- Builders use to construct streets and buildings.

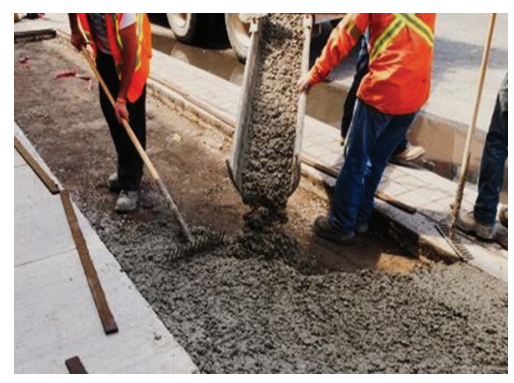

17- My mother put all the plates and the glasses in the

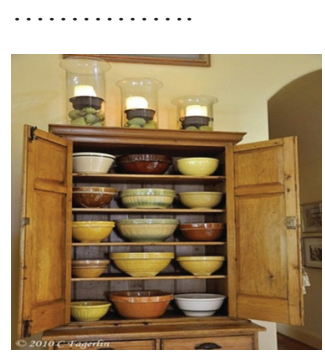

18- I put water in a...

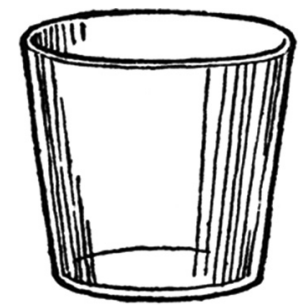

19- If I do not drink while studying, I will not concentrate.

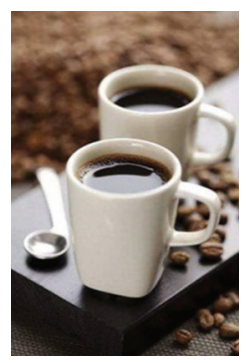

20- When I buy

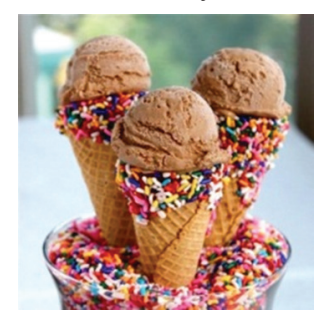

21- I put it in the so that it does not melt.

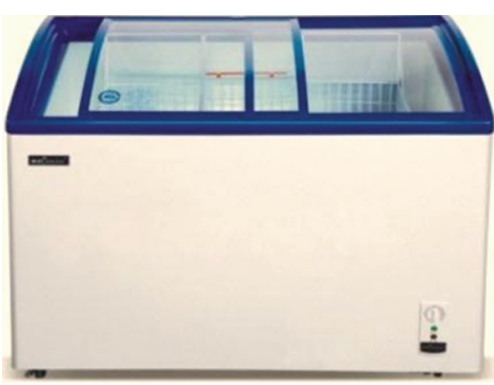

22- I put to my phone so that my younger brother would not access it.

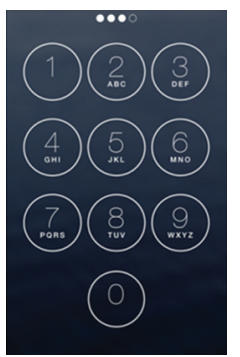

23- When I graduated, I put my graduation picture in a .............. and hung it on the wall.

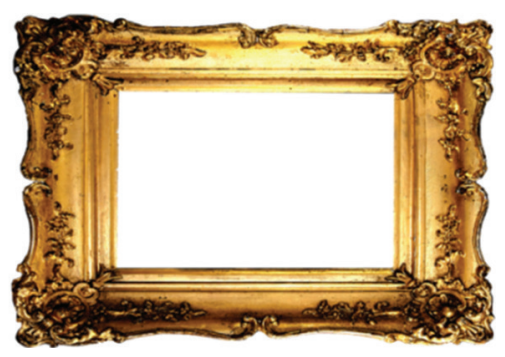

24- When my phone battery dies, I use a to charge it

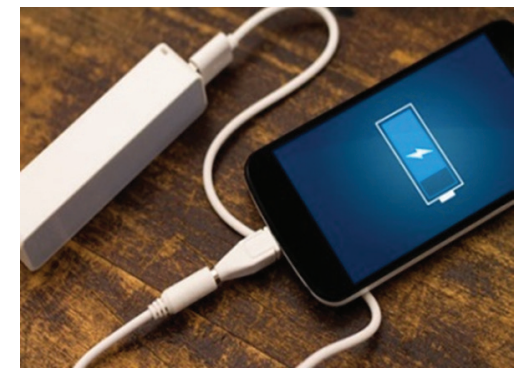


25- What is the colour of this car?

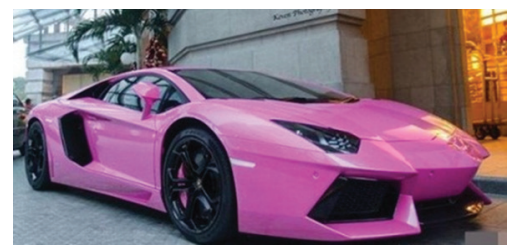

26- I go to ADNOC to refill my car with

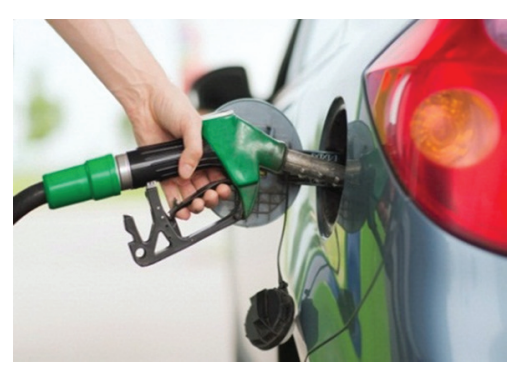

27- I went to the supermarket, bought some stuff, and put them in $\mathrm{a} . . . . . . . . . . . . .$.

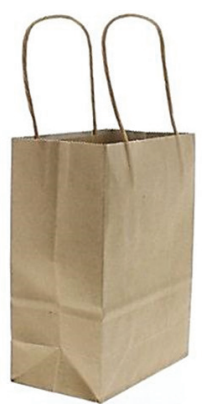

28- This

is in a brown attire and is holding a weapon.

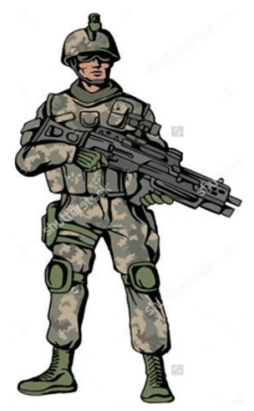

29- I need to put a .on an envelope before posting it.

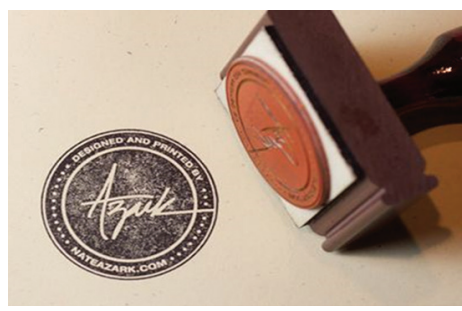

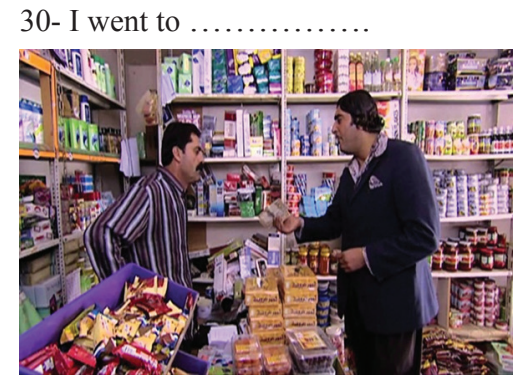

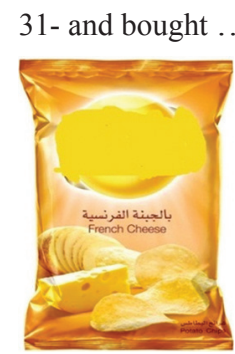

32- Mathematics is a difficult subject, but our ............. is very clever and knows how to make it easy on us.

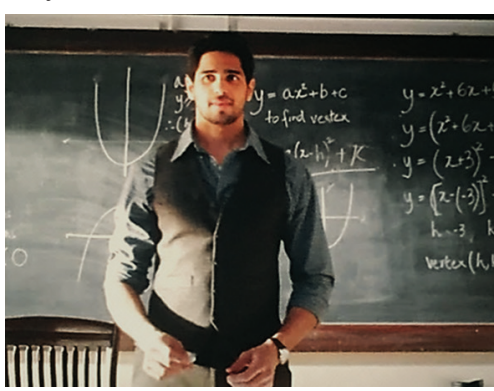

33- My friend moved to a new so I must visit him/her.

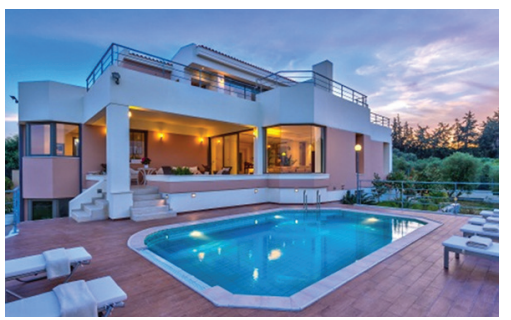

34- I cannot drive a car If I do not have a

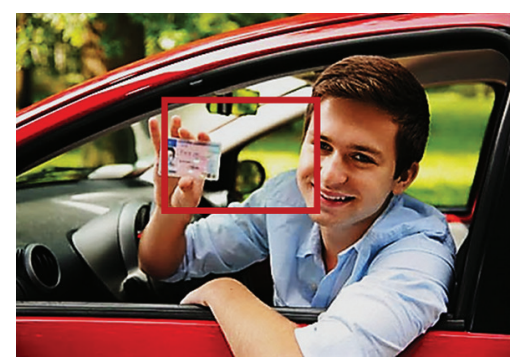


35- Ladies use

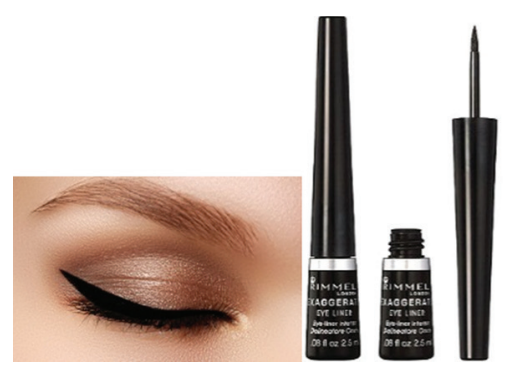

36- I need to put a ..............on my phone so that I does not beak if I drop it down by mistake.

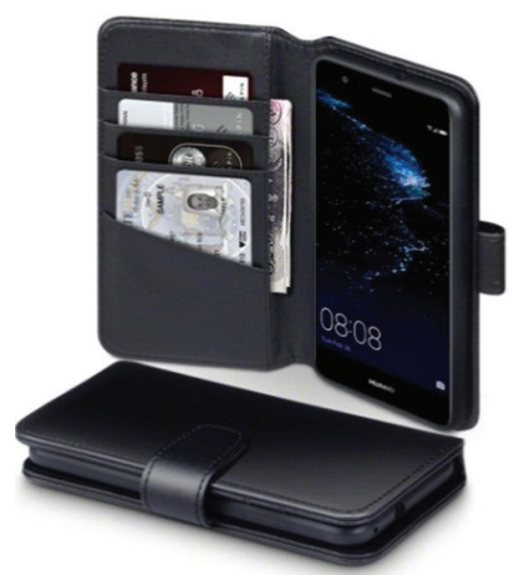

37- When I arrived home, I parked my car in the

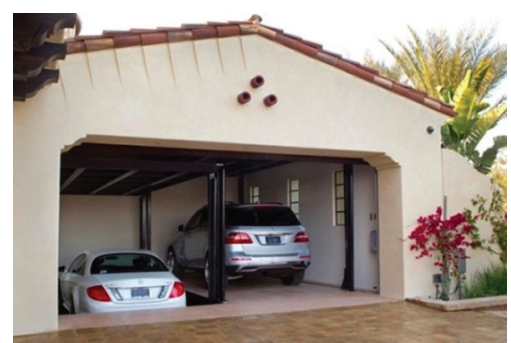

38- I could not find my friend's place, so I told him/her to

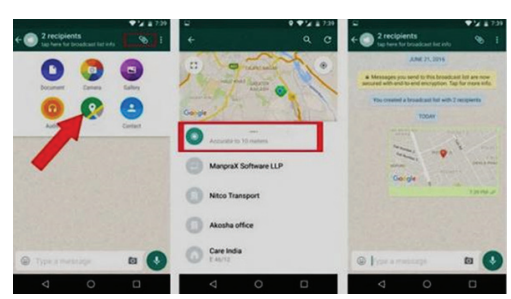

39- He/she told me not drive left or right, and that I only go

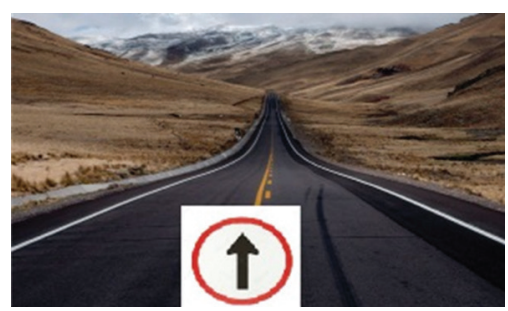

40- When I drink my stomach gets much better.

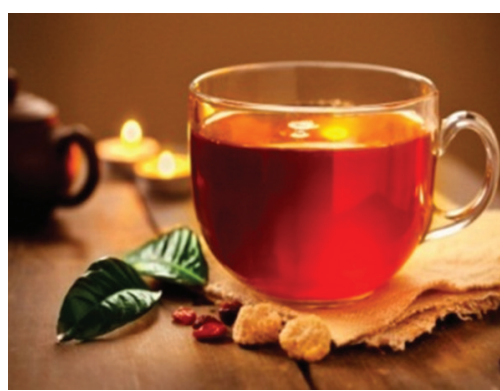

41- I lost my nephew in the mall, so I asked. to help me find him.

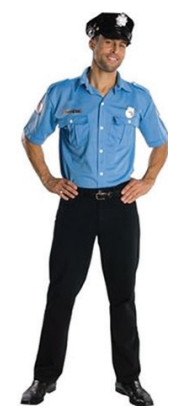

42- If I am to look good, my shirt and must be clean.

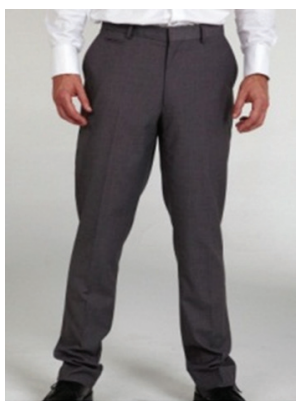

43- I get very happy when my favourite team scores a

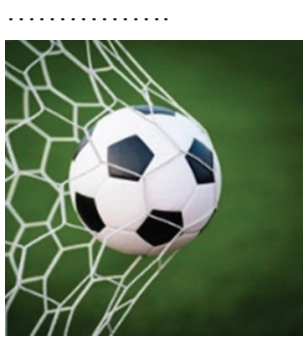

44- My ...is very easy to use.

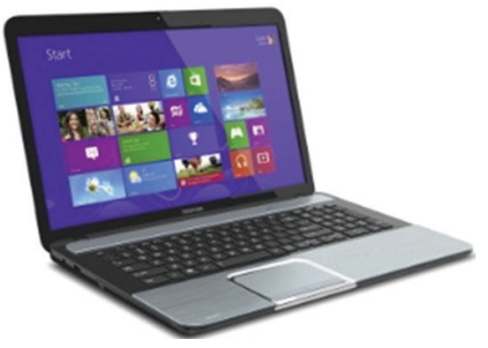


45- When I fell sick, I went to the

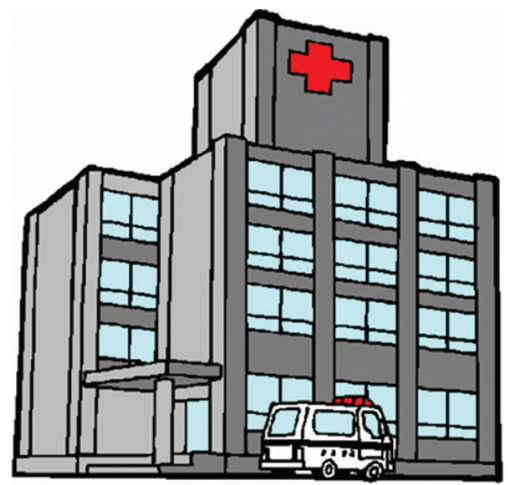

46- The. cured me.

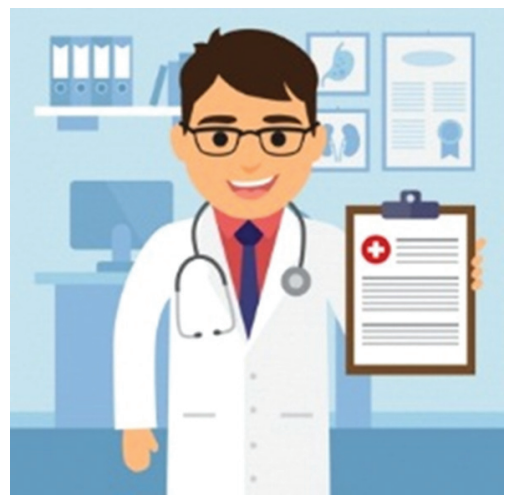

47- and gave me for joint pain

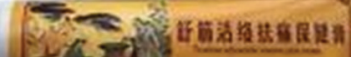
$+2,27$

(i:.:

$20 x+2=0$ 3......

What do you call these things?
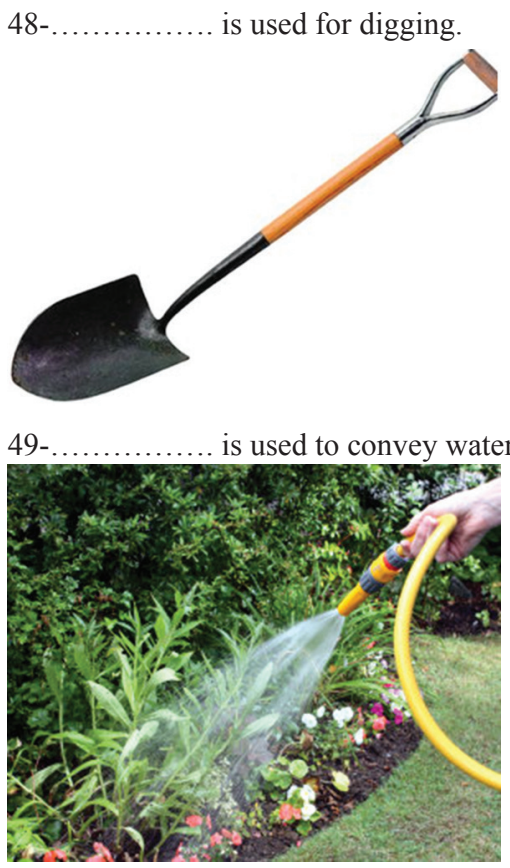

50- I must have to stay in touch with my friends.

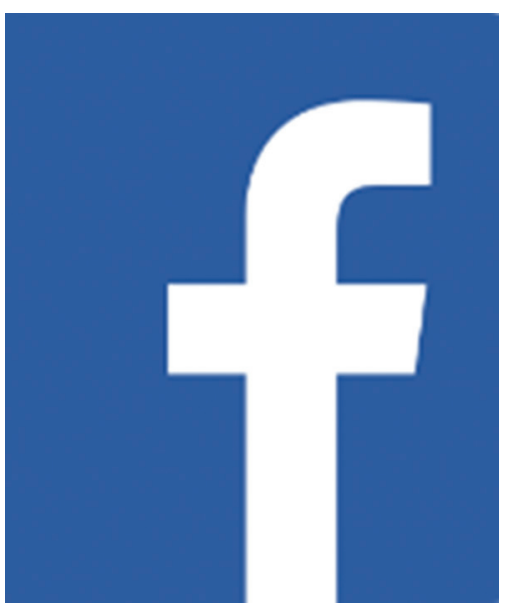

